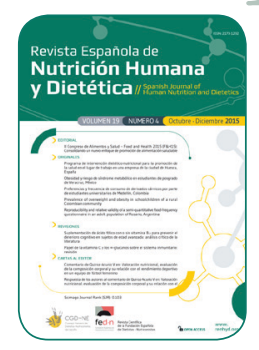

ORIGINAL

\title{
Prevalence of overweight and obesity in schoolchildren of a rural Colombian community
}

\author{
Rubén Andrés Ortega-Bonilla ${ }^{a, *}$, Diana Maria Chito-Trujillo \\ a Facultad de Ciencias, Universidad Autónoma de Madrid, Madrid, España. \\ b Facultad de Ciencias Naturales Exactas y de la Educación, Departamento de Química, Universidad del Cauca, Popayán, Colombia. \\ *andres.ortega@estudiante.uam.es
}

Received: 13/08/2015; accepted: 28/10/2015.

Prevalence of overweight and obesity in schoolchildren of a rural Colombian community

\section{KEYWORDS}

Ethnic groups;

Body Mass Index;

Obesity;

Overweight;

Prevalence;

Students.

\begin{abstract}
AB STRACT
Introduction: The National Survey of the Nutritional Situation in Colombia does not establish the nutritional state of entire population living in the rural area of 32 departments that constitute the political division of Colombia. The purpose of this study was to assess the trends of nutritional status in school community in some rural and remote areas of Cauca department in the South of Colombia with emphasis on excess of weight.

Material and Methods: Cross-sectional descriptive study of 6,664 schoolchildren of both genders, between 4 and 19 years of age from 12 schools was performed. Height and weight measurements were used to calculate body mass index and the prevalence of overweight and obesity were defined based on internationally accepted cut-off points. Gender, age, ethnicity and municipality were evaluated as factors associated to excess weight according to body mass index.

Results: The mean of age was $13.2 \pm 2.9$ years; $52.0 \%$ males and $48.0 \%$ aboriginal schoolchildren. School population was greater in the south and east of Cauca. Regarding nutritional status, almost $4.0 \%$ of students were in excess weight being significantly predominant the obesity in females. $55.2 \%$ of schoolchildren present normal values of body mass index.

Conclusions: Low prevalence of overweight (3.3\%) and obesity (0.3\%) were correlated to adolescent students from South and Eastern Cauca. Although the rural schoolchildren obesity prevalence is low, the findings suggest implying proper and prompt interventions from alliances of national and global organizations in order to avoid immediate solutions that may promote the current nutritional status.
\end{abstract}


Prevalencia de sobrepeso y obesidad en escolares de una comunidad rural Colombiana

PALABRAS CLAVE
Grupos étnicos;
Índice de Masa
Corporal;
Obesidad;
Sobrepeso;
Prevalencia;
Estudiantes.

\section{RESUMEN}

Introducción: La Encuesta Nacional de la Situación Nutricional en Colombia no establece el estado nutricional de la población completa que vive en el área rural de los 32 departamentos que constituyen la división política de Colombia. El propósito de este estudio fue evaluar las tendencias nutricionales de la comunidad escolar en algunas áreas rurales y remotas del Departamento del Cauca en el Sur de Colombia con énfasis en el exceso de peso.

Material y Métodos: Se desarrolló un estudio descriptivo transversal de 6.664 escolares de ambos géneros, entre 4 y 19 años de edad procedentes de 12 colegios. Se usaron mediciones de talla y peso para calcular el índice de masa corporal y se definió la prevalencia de sobrepeso y obesidad en función de los valores de corte aceptados internacionalmente. Género, edad, etnia y municipalidad se evaluaron como factores asociados al exceso de peso de acuerdo al índice de masa corporal.

Resultados: La edad promedio fue $13,2 \pm 2,9$ años; $52,0 \%$ hombres y $48,0 \%$ escolares indígenas. El sur y el este del Cauca registraron la mayor población escolar. Respecto al estado nutricional, casi el 4,0\% de estudiantes tuvo un exceso de peso siendo predominante significativamente la obesidad en mujeres. Un 55,2\% de escolares presentaron valores normales de índice de masa corporal.

Conclusiones: Una baja prevalencia de sobrepeso $(3,3 \%)$ y obesidad $(0,3 \%)$ se correlacionó con los estudiantes del Sur y Oriente del Cauca; los hallazgos sugieren involucrar adecuadas y prontas intervenciones mediante alianzas de organizaciones nacionales e internacionales para evitar soluciones inmediatistas que puedan potenciar los actuales estados nutricionales.

\section{CITA} community. Rev Esp Nutr Hum Diet. 2015; 19(4): 212 - 220. DOI: 10.14306/renhyd.19.4.176

\section{INTRODUCTION}

Excess weight has been declared as a major public health problem and worldwide epidemic ${ }^{1}$. It can occur as overweight or obesity which are defined as abnormal or excessive fat accumulation that may impair health². During the last two decades, numerous evidences and trends in regard to the prevalence of overweight and obesity, as well as their risk factors for health have been reported by investigators from different countries ${ }^{3-6}$. There is no a consensus on which is the best method and which are the ideal cut-off to diagnostic the excess weight. However, the computation of Body Mass Index (BMI) is a global recognized method. The problematic of abnormal or excessive fat accumulation is neither limited to an only age group nor developed countries; it has reached a growing importance in developing countries due to the easy availability of dense foods, as well as in pediatric and adolescent groups because of their prioritization for the implementation of programmes to monitor and prevent the obesity. To date, World Health Organization reports that at least 2.8 million people die each year as a result of their overweight or obese status in the world ${ }^{2}$. Recently, it was estimated that average 24.1 million children (5-11 years) and 18.8 million adolescents (12-19 years) were overweight or obese conditions in Latin America?. Excess weight conditions are currently prevalent in Colombia. In fact, Colombian government together with its Ministry of Social Protection decreed in 2009 obesity and associated no communicable diseases like a public health priority and declare to September 24 as national day against obesity and overweight ${ }^{8}$. According to Number and Indicators in Health, 
the Report of Disease in Colombia9; Statistics of Public Health Monitoring and the National Health Survey ${ }^{10}$; and the most recent National Survey of Nutritional Status (ENSIN 2010)11; one in six Colombian children and adolescents (5-17 years) were overweight or obese. In addition, the excess weight resulted higher in urban (19.2\%) regions than rural (13.4\%). These statistics showed the Cauca department as the third province (21.7\%), after San Andrés and Guaviare, with prevalence of excess weight conditions. Although national surveys, the broadest analysis, have been performed on 2005 and 2010 11,12 , the collected data do not include descriptive information from each one of the municipalities of each department in Colombia. Hence, the goal of the present study was to assess the trend in the prevalence of overweight and obesity of schoolchildren residing in twelve municipalities of the Department of Cauca (Colombia). This study also attempted to identify the regions of prevalence in that province and their association with ethnic groups of the population using bivariate statistical analysis. This information should complement the national data reported by government institutions for scientifically support the planning healthcare related corrective measures.

\section{MATERIAL AND METHODS}

\section{Data collection}

Cauca department is one of the 32 provinces that make up Colombia, located in south-western and comprises 42 municipalities. Data used in this analysis were students' growth parameters collected in a survey of schoolchildren of the main educational institutions located in the selected municipalities of the department of Cauca, aged between 4 and 19 years, enrolled from first grade of elementary school to eleven grade of high school, and residing in some town of the south (Almaguer, 20,463 inhabitants; Argelia, 24,538 inhabitants; Bolívar, 43,461 inhabitants; La Vega, 33,133 inhabitants; Piamonte, 7,083 inhabitants; Santa Rosa, 9,579 inhabitants; San Sebastián, 13,027 inhabitants), north (Miranda, 31,967 inhabitants) and eastern (Jambaló, 14,831 inhabitants; Puracé, 16,892 inhabitants; Totoró, 17,430 inhabitants; Paez, 31,548 inhabitants) of Cauca. Data collection was leader by PANES (Plan de Alimentación y Nutrición Escolar) program. These geographic areas were selected due to have been either place historically affected by armed conflict or with difficult access to food. All parents of the infants and the chancellors of the schools participating in the projects were informed about the purpose, procedures, and privacy of the measurements and signed an informed consent form. Training about taking proper measurements of weight and height was given by a contracted expert in nutrition and dietetics. The indicators reported were: height, weight, gender, ethnicity and area of residence. $\mathrm{BMI}$ was calculated as weight $(\mathrm{kg})$, divided by the squared of height (m). Height-for-age and BMI-for-age were indicators assessed in schoolchildren according to standard classification proposed by World Health Organization ${ }^{13}$. The study did not require ethics review, since this is a secondary analysis of deidentified publicly available data.

\section{Data analysis}

Means and standard deviations of height, weight and frequency percentage of gender, ethnic, BMI and municipalities were calculated. ANOVA test with alpha 0.05 was used to compare the differences in mean values of age, weight and height and frequency values of ethnicity and geographical in respect to gender. Pearson correlations were fixed between some variables with a significance level $<0.01$. Associations between BMI and gender, age, origin and ethnicity were established by means of cross-tabs using Chi square with a confidence interval 95\%. Results are considered statistically significant at level $<0.05$.

Standard deviation scores (SDS) for three nutritional indicators (height, weight and BMI) adjusted for ages were estimated from individual data. "Short" children (SDS height below -1) or "tall" children (SDS height above +1 ); in respect to weight and BMI indicators, the Z-Score distribution can depart slightly from normality at the extreme tails (beyond \pm 3 SD). Calculation of the SDS values was based on the national reference data for $\mathrm{BMI}$, height and weight of $\mathrm{WHO}$ by applying of AnthroPlus software ${ }^{14}$.

Statistical analyses were performed with SPSS v.20 software.

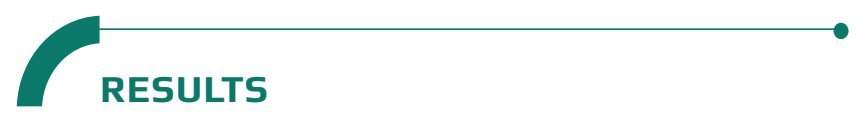

Data collected from 6,664 students were included. Total sample correspond to children enrolled in the main educational institutions of twelve rural regions of the Department of Cauca. Table 1 details anthropometric and sociodemographic characteristics of the sample. The mean value and standard deviation of age, weight and height were $13.2 \pm 2.9$ years, $42.6 \pm 12.0 \mathrm{~kg}$ and $1.47 \pm 0.24 \mathrm{~m}$, respectively. Half of the total of sample ranged between 11 and 15 years. Male (52.0\%) and aboriginal (48.0\%) schoolchildren slightly predominate on female and the rest of ethnicity. According to $\mathrm{BMI}$ standard classification, most students of the sample (55.2\%) fell into the group with a BMI normal. Schoolchildren 
Table 1. Descriptive analysis results among rural schoolchildren from 12 municipalities of the department of Cauca, Colombia, in 2009.

\begin{tabular}{|c|c|}
\hline Characteristics & Sample $(n=6,664)$ \\
\hline \multicolumn{2}{|l|}{ Age (years) } \\
\hline Average $\pm S D$ & $13.2 \pm 2.9$ \\
\hline Median (IQR) & $13.0(11.0-15.0)$ \\
\hline \multicolumn{2}{|l|}{ Gender, n (\%) } \\
\hline Male & $3,466(52.0)$ \\
\hline \multicolumn{2}{|l|}{ Ethnicity, n (\%) } \\
\hline Afro & $356(5.3)$ \\
\hline Aboriginal & $3,197(48.0)$ \\
\hline Mestizo & $3,111(46.7)$ \\
\hline \multicolumn{2}{|l|}{ Weight (kg) } \\
\hline Average $\pm S D$ & $42.6 \pm 12.0$ \\
\hline Median (IQR) & $43.0(34.0-51.0)$ \\
\hline \multicolumn{2}{|l|}{ Height (m) } \\
\hline Average $\pm S D$ & $1.47 \pm 0.24$ \\
\hline Median (IQR) & $1.49(1.38-1.57)$ \\
\hline \multicolumn{2}{|c|}{ BMI classification, n (\%) } \\
\hline Underweight & $2,739(41.1)$ \\
\hline Normal & $3,679(55.2)$ \\
\hline Overweight & $223(3.3)$ \\
\hline Obese & $23(0.3)$ \\
\hline \multicolumn{2}{|c|}{ Municipality, n (\%) } \\
\hline Almaguer & $53(0.8)$ \\
\hline Argelia & $1,528(22.9)$ \\
\hline Bolívar & $1,049(15.7)$ \\
\hline Jambaló & 738 (11.1) \\
\hline La Vega & $522(7.8)$ \\
\hline Miranda & $172(2.6)$ \\
\hline Paez & $476(7.1)$ \\
\hline Piamonte & $231(3.5)$ \\
\hline Purace & $488(7.3)$ \\
\hline San Sebastián & 659 (9.9) \\
\hline Santa Rosa & $425(6.4)$ \\
\hline Totoró & $323(4.8)$ \\
\hline
\end{tabular}

SD: Standard deviation; IQR: Interquartile range.

mainly are from the municipalities of Argelia (22.9\%), Bolívar (15.7\%) and Jambaló (11.1\%).

The mean values and standard deviation of age $(p=0.014)$ and height $(p=0.000)$ in male were significantly higher than in female (Table 2). Similar mean values of weight in male and female were found which showed no significant differences $(p=0.470)$. Slight differences no significant $(p=0.262)$ between the percentages of frequency of three types of ethnicity by gender were detected. BMI classification showed percentages significantly lower of women classified 
Table 2. Classification by gender of sociodemographic and nutritional characteristics of rural schoolchildren from 12 municipalities of the department Cauca, Colombia, in 2009.



SD: Standard deviation; IQR: Interquartile range. ${ }^{*} \boldsymbol{p}<0.05$

in underweight and normal but percentages of BMI classified as overweight and obese higher than men. Regarding to geographic origin of schoolchildren, significant differences defined by municipalities of Argelia and La Vega were observed. Most of boys were from La Vega and women from Argelia.

\section{Prevalence of excess weight}

Table 1 shows the prevalence of low weight or normal status in the analysed sample. Excess weight was diagnosed in less than $5 \%$ of schoolchildren, with $0.3 \%$ being obese and $3.3 \%$ overweight. Normal status was predominantly diagnosed in $55.2 \%$ of sample followed by $41.1 \%$ of children with low weight.

BMI in female schoolchildren had a prevalence percentage (5.3\%) of excess weight significantly higher than children male $(2.2 \%)$ in the bivariate analysis (Table 2 ). In contrast, male had a greater chance (44.0\%), statistically significant, 
of having underweight in relation to female schoolchildren (38.0\%).

\section{Nutritional assessment}

Nutritional indicators (weight-for-age, height-for-age and BMI-for-age) were estimated by means of determination of Z-Scores in the AnthroPlus software ${ }^{14}$.

Weight-for-age: a moderate and significant correlation $(r=0.787 ; p<0.01)$ between weight and age was observed whereby it is assumed that a certain proportion of schoolchildren do not have a proper weight for their age. Over $70 \%$ of sample overcomes the average age (13.2 years). Thus, the estimations were not calculated for the entire population given that the reference data were not available beyond age 10 because this indicator does not distinguish between height and body mass in an age period where many children are experiencing the pubertal growth spurt and may appear as having excess weight (by weight-for-age) when, in fact, they are just tall. Hence, the software computed the estimation for twelve children aged less than 10 years (data no represented). This sub-sample evidenced an asymmetric and shifted distribution compared to the reference as a consequence of a low percentage of schoolchildren (less than 5\%) with more than 3 SD. These results could be considered as predictive of the nutritional risk of the schoolchildren.

Height-for-age: experimental distributions for both gender differed between -1 and -2 SD from the reference, placing a greater proportion of female schoolchildren in that range. From a nutritional point of view, these findings indicate that male and female students to 19 years potentially would exhibit growth retardation.

BMI-for-age: male schoolchildren had a tendency to follow behaviour of the standard curve (data no depicted). In the case of female students, the distribution lost the symmetry from the reference. These results confirm the prevalence of excess of weight (overweight and obesity) in female schoolchildren described in Table 2.

\section{DISCUSSION}

Results from this retrospective study show a low prevalence of overweight and obesity in schoolchildren of rural regions of the Department of Cauca being more pronounced the overweight $(3.3 \%$ vs. $0.3 \%$, Table 1$)$. These nutritional classifications defined according to BMI rank the third and fourth position after normality that is the first and underweight in a second. The prevalence in female students (5.3\%) is significantly almost three times higher than that of male (2.2\%). Schoolchildren under these status are residents in the municipalities of San Sebastian and Argelia, being statistically higher female gender $(p=0.000)$ from the first one origin, aged between 12 and 19 years with a statistical contribution higher from schoolchildren in between 16 to 19 years $(p=0.000)$, and from mestizo ethnicity, see Table 3 .

A prevalence of underweight statistically higher in male was found in Argelia and Bolivar focused in children in between 4 and 8 years in Argelia and 12 and 15 years in Bolívar. The findings of Argelia are in agreement with reported in ${ }^{15}$. The ethnicity characteristic with this status of prevalence was mestizo. Normal status had prevalence in children in between 12 and 15 years from municipalities of Jambaló, La Vega, Miranda, Paez, Piamonte, Puracé, San Sebastián, Santa Rosa and Totoró, being significantly higher in children female than male, except in Jambaló, La Vega and San Sebastian. Aboriginal ethnicity predominated except in Miranda, San Sebastian, and Santa Rosa, where mestizo was slightly higher.

Findings do not show an alarming prevalence of excess of weight; instead underweight reported as the main nutritional problem of Colombian until $2005^{12}$ children keeps the tendency. Hence, the obtained trend with these data collected in 2009 could be an indicator of dramatic changes.

Multiple factors that affect the trend of overweight and obesity according to gender are documented ${ }^{16,17}$, but it is clear any kind of excess weight implies health consequences ${ }^{18,19}$. The reasons or factors directly associated to these findings could not be ascertained, but they may be understood from real marked differences in lifestyle of girls and boys in these rural regions. Women are usually dedicated to housework close to their mothers, while men assist their fathers in farm activities that may involve more effort. In addition, controversies related to immunization safety have led to an increasing number of parents who refuse to vaccinate their children. Health care professionals argued on the benefit of avoiding preventable diseases which are correlated to nutritional disorders ${ }^{20,21}$. A high risk for worm infectious has been detected in rural communities due to raw or insufficiently cooked food, frequent use of river water (unsafe water) and low acceptance of appropriate preventive treatment during collective campaign. It is known that the lack of deworming treatments have a negative impact on nutrition process. Another point that should be considered for children of rural regions of developing countries is the problem of low birth weight, which by itself or accompanied with a rapid growth spurt during childhood 22 makes one 
Rev Esp Nutr Hum Diet. 2015; 19(4): 212 - 220

Prevalence of overweight and obesity in schoolchildren of a rural Colombian community

Table 3. Associations by municipality between nutritional status of rural schoolchildren of the Cauca department enrolled in 2009 and gender, ethnicity and age.

Nutritional Status

Ethnicity

Age by ranges (years)

\begin{tabular}{|c|c|c|c|c|c|c|c|c|c|c|c|c|}
\hline Municipality & M & $F$ & ${ }^{*} p$-value & Afro & Aboriginal & Mestizo & *p-value & 4-8 & $9-11$ & $12-15$ & $16-19$ & ${ }^{*} p$-value \\
\hline $\begin{array}{l}\text { Almaguer } \\
\text { Underweight } \\
\text { Normal } \\
\text { Overweight } \\
\text { Obesity }\end{array}$ & $\begin{array}{l}13 \\
24 \\
0 \\
0\end{array}$ & \begin{tabular}{c|}
1 \\
14 \\
1 \\
0
\end{tabular} & 0.029 & & $\begin{array}{c}14 \\
38 \\
1 \\
0\end{array}$ & & - & & & $\begin{array}{c}10 \\
19 \\
0 \\
0\end{array}$ & $\begin{array}{c}4 \\
19 \\
1 \\
0\end{array}$ & 0.217 \\
\hline $\begin{array}{l}\text { Argelia } \\
\text { Underweight } \\
\text { Normal } \\
\text { Overweight } \\
\text { Obesity }\end{array}$ & $\begin{array}{c}492 \\
279 \\
15 \\
0\end{array}$ & $\begin{array}{c}452 \\
270 \\
18 \\
2\end{array}$ & 0.454 & $\begin{array}{l}8 \\
9 \\
0 \\
0\end{array}$ & & $\begin{array}{c}936 \\
540 \\
33 \\
2\end{array}$ & 0.256 & $\begin{array}{c}454 \\
41 \\
0 \\
0\end{array}$ & $\begin{array}{l}285 \\
106 \\
5 \\
0\end{array}$ & $\begin{array}{c}186 \\
261 \\
12 \\
0\end{array}$ & $\begin{array}{c}19 \\
141 \\
16 \\
2\end{array}$ & 0.000 \\
\hline $\begin{array}{l}\text { Bolivar } \\
\text { Underweight } \\
\text { Normal } \\
\text { Overweight } \\
\text { Obesity }\end{array}$ & $\begin{array}{c}316 \\
230 \\
6 \\
2\end{array}$ & $\begin{array}{c}225 \\
250 \\
17 \\
3\end{array}$ & 0.000 & $\begin{array}{l}62 \\
55 \\
4 \\
1\end{array}$ & $\begin{array}{c}159 \\
135 \\
5 \\
0\end{array}$ & $\begin{array}{c}320 \\
290 \\
14 \\
4\end{array}$ & 0.769 & & $\begin{array}{c}150 \\
36 \\
2 \\
1\end{array}$ & $\begin{array}{c}343 \\
278 \\
13 \\
2\end{array}$ & $\begin{array}{c}48 \\
166 \\
8 \\
2\end{array}$ & 0.000 \\
\hline $\begin{array}{l}\text { Jambaló } \\
\text { Underweight } \\
\text { Normal } \\
\text { Overweight } \\
\text { Obesity }\end{array}$ & $\begin{array}{c}123 \\
270 \\
6 \\
0\end{array}$ & $\begin{array}{c}93 \\
225 \\
21 \\
0\end{array}$ & 0.003 & & $\begin{array}{c}216 \\
495 \\
27 \\
0\end{array}$ & & - & & $\begin{array}{c}97 \\
63 \\
0 \\
0\end{array}$ & $\begin{array}{c}118 \\
283 \\
10 \\
0\end{array}$ & $\begin{array}{c}1 \\
149 \\
17 \\
0\end{array}$ & 0.000 \\
\hline $\begin{array}{l}\text { La Vega } \\
\text { Underweight } \\
\text { Normal } \\
\text { Overweight } \\
\text { Obesity }\end{array}$ & $\begin{array}{c}60 \\
239 \\
6 \\
0\end{array}$ & \begin{tabular}{c|}
38 \\
163 \\
14 \\
2
\end{tabular} & 0.003 & & $\begin{array}{c}98 \\
402 \\
20 \\
2\end{array}$ & & - & & $\begin{array}{l}7 \\
8 \\
0 \\
0\end{array}$ & $\begin{array}{c}74 \\
201 \\
6 \\
1\end{array}$ & $\begin{array}{c}17 \\
193 \\
14 \\
1\end{array}$ & 0.001 \\
\hline $\begin{array}{l}\text { Miranda } \\
\text { Underweight } \\
\text { Normal } \\
\text { Overweight } \\
\text { Obesity }\end{array}$ & $\begin{array}{l}23 \\
58 \\
2 \\
0\end{array}$ & $\begin{array}{c}16 \\
66 \\
6 \\
1\end{array}$ & 0.172 & & & $\begin{array}{c}39 \\
124 \\
8 \\
1\end{array}$ & - & & $\begin{array}{l}0 \\
2 \\
0 \\
0\end{array}$ & $\begin{array}{c}37 \\
79 \\
5 \\
1\end{array}$ & $\begin{array}{l}2 \\
43 \\
3 \\
0\end{array}$ & 0.031 \\
\hline $\begin{array}{l}\text { Paez } \\
\text { Underweight } \\
\text { Normal } \\
\text { Overweight } \\
\text { Obesity }\end{array}$ & $\begin{array}{c}100 \\
139 \\
6 \\
1\end{array}$ & $\begin{array}{c}75 \\
144 \\
11 \\
0\end{array}$ & 0.104 & $\begin{array}{c}69 \\
114 \\
8 \\
0\end{array}$ & $\begin{array}{c}85 \\
145 \\
7 \\
1\end{array}$ & $\begin{array}{c}21 \\
24 \\
2 \\
0\end{array}$ & 0.801 & & $\begin{array}{c}89 \\
45 \\
2 \\
1\end{array}$ & $\begin{array}{c}81 \\
170 \\
10 \\
0\end{array}$ & $\begin{array}{c}5 \\
68 \\
5 \\
0\end{array}$ & 0.000 \\
\hline $\begin{array}{l}\text { Piamonte } \\
\text { Underweight } \\
\text { Normal } \\
\text { Overweight } \\
\text { Obesity }\end{array}$ & $\begin{array}{c}54 \\
59 \\
6 \\
1\end{array}$ & \begin{tabular}{c|}
42 \\
64 \\
5 \\
0
\end{tabular} & 0.489 & $\begin{array}{c}9 \\
13 \\
4 \\
0\end{array}$ & $\begin{array}{c}87 \\
110 \\
7 \\
1\end{array}$ & & 0.143 & & $\begin{array}{c}22 \\
10 \\
0 \\
0\end{array}$ & $\begin{array}{c}61 \\
56 \\
8 \\
1\end{array}$ & $\begin{array}{l}13 \\
57 \\
3 \\
0\end{array}$ & 0.000 \\
\hline $\begin{array}{l}\text { Puracé } \\
\text { Underweight } \\
\text { Normal } \\
\text { Overweight } \\
\text { Obesity }\end{array}$ & $\begin{array}{c}79 \\
142 \\
4 \\
3\end{array}$ & $\begin{array}{c}63 \\
178 \\
19 \\
0\end{array}$ & 0.001 & & $\begin{array}{c}75 \\
177 \\
15 \\
0\end{array}$ & $\begin{array}{c}67 \\
143 \\
8 \\
3\end{array}$ & 0.174 & & $\begin{array}{l}61 \\
37 \\
1 \\
1\end{array}$ & $\begin{array}{c}76 \\
203 \\
11 \\
0\end{array}$ & $\begin{array}{c}5 \\
80 \\
11 \\
2\end{array}$ & 0.000 \\
\hline $\begin{array}{l}\text { San Sebastián } \\
\text { Underweight } \\
\text { Normal } \\
\text { Overweight } \\
\text { Obesity }\end{array}$ & $\begin{array}{c}78 \\
243 \\
8 \\
1\end{array}$ & $\begin{array}{c}87 \\
209 \\
28 \\
5\end{array}$ & 0.000 & & $\begin{array}{c}82 \\
226 \\
20 \\
0\end{array}$ & $\begin{array}{c}83 \\
226 \\
16 \\
6\end{array}$ & 0.095 & & $\begin{array}{l}70 \\
47 \\
1 \\
0\end{array}$ & $\begin{array}{c}91 \\
264 \\
16 \\
2\end{array}$ & $\begin{array}{c}4 \\
141 \\
19 \\
4\end{array}$ & 0.000 \\
\hline $\begin{array}{l}\text { Santa Rosa } \\
\text { Underweight } \\
\text { Normal } \\
\text { Overweight } \\
\text { Obesity }\end{array}$ & $\begin{array}{c}94 \\
117 \\
5 \\
1\end{array}$ & \begin{tabular}{c|}
63 \\
129 \\
15 \\
1
\end{tabular} & 0.007 & & $\begin{array}{c}90 \\
121 \\
13 \\
0\end{array}$ & $\begin{array}{c}67 \\
125 \\
7 \\
2\end{array}$ & 0.101 & & $\begin{array}{c}47 \\
16 \\
2 \\
1\end{array}$ & $\begin{array}{c}102 \\
135 \\
10 \\
1\end{array}$ & $\begin{array}{c}8 \\
95 \\
8 \\
0\end{array}$ & 0.000 \\
\hline $\begin{array}{l}\text { Totoró } \\
\text { Underweight } \\
\text { Normal } \\
\text { Overweight } \\
\text { Obesity }\end{array}$ & $\begin{array}{l}92 \\
68 \\
1 \\
0\end{array}$ & $\begin{array}{c}60 \\
99 \\
3 \\
0\end{array}$ & 0.001 & & $\begin{array}{c}152 \\
167 \\
4 \\
0\end{array}$ & & - & & $\begin{array}{c}49 \\
14 \\
0 \\
0\end{array}$ & $\begin{array}{l}95 \\
92 \\
2 \\
0\end{array}$ & $\begin{array}{c}8 \\
61 \\
2 \\
0\end{array}$ & 0.000 \\
\hline
\end{tabular}


prone to no communicable diseases. The escalating trends in excess weight of Colombian schoolchildren may be an accumulating risk for those who were underweight at birth.

A remarkable point is the ethnic predisposition to adverse health effects of obesity and overweight ${ }^{23,24}$. In this sense, mestizo and aboriginal ethnicities predominant in underweight and normal status could undergo long-term health effects.

\section{$\longrightarrow$ \\ CONCLUSIONS}

This paper, which is likely the first of its kind covering large part of the rural area of Cauca department, provides BMI data based on measured weight and height for schoolchildren between 4 and 19 years. It was detected a low prevalence of excess weight (3.6\%), even below recent national reports (ENSIN, 13.4\%), which was associated mainly to schoolchildren female in between 12 and 19 years of the municipalities of south (San Sebastian, Argelia and Bolivar) and eastern (Jambaló and Puracé) of the department, mainly of mestizo and aboriginal ethnicities, suggesting that an important contribution should be considered in initiatives at regional and national levels related to preventive programmes and interventions futures addressed to decrease these factors in rural population.

\section{ACKNOWLEDGEMENTS}

Authors give thanks to PANES Program of the Government of Cauca who cooperated with this study.

\section{$\longrightarrow$ \\ COMPETING INTERESTS}

The authors declare have no conflict of interests to draft the manuscript.

\section{BIBLIOGRAPHY}

1. Haththotuwa RN, Wijeyaratne $\mathrm{CN}$, Senarath U. Worldwide Epidemic of Obesity. In: Arulkumaran TM, editor. Obesity. Oxford: Elsevier; 2013. p. 3-11.

2. World Health Organization. Obesity and overweight [Internet].
WHO. 2014 [cited 2014 Sep 7]. Available from: http://www. who.int/mediacentre/factsheets/fs311/en/

3. Cavaco S, Eriksson T, Skalli A. Life cycle development of obesity and its determinants in six European countries. Econ Hum Biol. 2014; 14: 62-78.

4. García García E, Vázquez López M-Á, Galera Martínez R, Alias I, Martín González M, Bonillo Perales A, et al. Prevalence of overweight and obesity in children and adolescents aged 2-16 years. Endocrinol Nutr. 2013; 60(3): 121-6.

5. Kelishadi R, Haghdoost A-A, Sadeghirad B, Khajehkazemi R. Trend in the prevalence of obesity and overweight among Iranian children and adolescents: a systematic review and meta-analysis. Nutrition. 2014; 30(4): 393-400.

6. Reinhold T, von Schultzendorff A, Müller-Riemenschneider F. Economic consequences of overweight and obesity in AsiaPacific. EuJIM. 2011; 3(1): 3-9.

7. Rivera JÁ, de Cossío TG, Pedraza LS, Aburto TC, Sánchez TG, Martorell R. Childhood and adolescent overweight and obesity in Latin America: a systematic review. Lancet Diabetes Endocrinol. 2014; 2(4): 321-32.

8. Congreso de Colombia. Ley 1355 de 2009 por medio de la cual se define la obesidad y las enfermedades crónicas no transmisibles asociadas a esta como una prioridad de salud pública y se adoptan medidas para su control, atención y prevención. 2009 p. 1-3.

9. Acosta N, Peñaloza RE, Rodríguez García J. Carga de Enfermedad Colombia 2005: Resultados Alcanzados [Internet]. Centro de proyección para el desarrollo (Cendex); 2008 [cited 2014 Sep 7]. Available from: http://www.javeriana.edu.co/ cendex/GPES/informes/PresentacionCarga_Informe.pdf

10. Instituto Nacional de Salud (Colombia). Estadísticas SIVIGILA [Internet]. Instituto Nacional de Salud. [cited 2014 Sep 14]. Available from: http://www.ins.gov.co/lineas-de-accion/ Subdireccion-Vigilancia/sivigila/Estadsticas\%20SIVIGILA/ Forms/public.aspx

11. Instituto Colombiano de Bienestar Familiar, editor. Encuesta nacional de la situación nutricional en Colombia 2010. Bogotá, Colombia: Instituto Colombiano de Bienestar Familiar; 2011.

12. Instituto Colombiano de Bienestar Familiar, editor. Encuesta nacional de la situación nutricional en Colombia, 2005. Bogotá, Colombia: Instituto Colombiano de Bienestar Familiar; 2006.

13. World Health Organization. Global Database on Body Mass Index [Internet]. WHO. 2014 [cited 2014 Aug 19]. Available from: http://apps.who.int/bmi/index.jsp

14. Blössner $M$, Siyam A, Borghi E, Onyango A, de Onis M. WHO AnthroPlus software [Internet]. Geneva: WHO; 2009 [cited 2014 Aug 19]. Available from: http://www.who.int/growthref/ tools/en/

15. Ortega-Bonilla RA, Chito-Trujillo DM. Valoración del estado nutricional de la población escolar del municipio de Argelia, Colombia. Rev Salud Pública (Bogotá). 2014; 16(4): 547-59.

16. Santiago S, Zazpe I, Martí A, Cuervo M, Martínez JA. Gender differences in lifestyle determinants of overweight prevalence in a sample of Southern European children. Obes Res Clin Pract. 2013; 7(5): e391-400.

17. Song HR, Park HS, Yun KE, Cho SH, Choi EY, Lee SY, et al. Gender and age differences in the impact of overweight on obesity-related quality of life among Korean adults. Obes Res Clin Pract. 2010; 4(1): e1-82. 
18. Pieniak Z, Pérez-Cueto F, Verbeke W. Association of overweight and obesity with interest in healthy eating, subjective health and perceived risk of chronic diseases in three European countries. Appetite. 2009; 53(3): 399-406.

19. Winston G], Caesar-Phillips E, Peterson JC, Wells MT, Martinez J, Chen $X$, et al. Knowledge of the health consequences of obesity among overweight/obese Black and Hispanic adults. Patient Educ Couns. 2014; 94(1): 123-7.

20. Marí-Bauset S, Zazpe I, Marí-Sanchis A, Llopis-González A, Suárez-Varela MM. Anthropometric measurements and nutritional assessment in autism spectrum disorders: A systematic review. Res Autism Spectr Disord. 2015; 9: 130-43.

21. Shea TB, Rogers E, Remington R. Chapter 77 - Nutritional Approaches to Mitigating Cognitive Decline and Maintaining Function in Alzheimer's Disease: Transgenic Mouse Models,
Combinatorial Approaches, and Dietary Supplementation with Folate and S-Adenosyl Methionine. In: Preedy CRMR, editor. Diet and Nutrition in Dementia and Cognitive Decline. San Diego: Academic Press; 2015. p. 837-45.

22. Imdad A, Bhutta ZA. Nutritional management of the low birth weight/preterm infant in community settings: a perspective from the developing world. J Pediatr. 2013; 162(3 Suppl): S107-14.

23. Delva J, O'Malley PM, Johnston LD. Racial/ethnic and socioeconomic status differences in overweight and healthrelated behaviors among American students: national trends 1986-2003. J Adolesc Health. 2006; 39(4): 536-45.

24. Monlux AA, Nigg CR. Obesity trends by ethnicity in Hawai' $i$ : The last ten years (1999-2008). Obes Res Clin Pract. 2011; 5(4): e267-360. 